\title{
Extended Web Assessment Method (EWAM) Sebuah Model untuk Mengukur Keberhasilan Aplikasi E-Commerce Berdasarkan Perspektif Konsumen
}

\author{
Andi Susilo ${ }^{1)}$, Yasmiati ${ }^{2)}$ \\ ${ }^{1), 2)}$ Program Studi Teknik Informatika, Fakultas Teknologi Informasi, Universitas Respati Indonesia \\ Jl. Bambu Apus I, N o. 3 Cipayung Jakarta 13890 \\ Telp. (021) 8454731, Faks. (021) 8457628 \\ E-mail:as@urindo.ac.id,yast_min@yahoo.com
}

\begin{abstract}
ABSTRAK
Extended Web Assessment Method (EWAM) adalah sebuah model untuk mengevaluasi dan menilai Aplikasi $e$ commerce dari perspektif konsumen. EWAM dikembangkan oleh Petra Schubert dan Dorian Selz di Universitas St. Gallen, Swiss. Metode ini secara utama mengintegrasikan temuan dari model Technology Acceptance Model (TAM) Davis dan teori Theory of Reasoned Action (TRA) dari Fishbein dan Ajzen. EWAM sebuah metode yang didasarkan kepada kisi evaluasi mencakup sekumpulan kriteria untuk menilai kualitas dan keberhasilan aplikasi-aplikasi e-commerce dan fitur-fitur yang spesifik dari Internet sebagai media. Pendekatan kuantitatif pada penelitian ini menggunakan statistik deskriptif dan analisis kualitatif. Sektor penjualan buku online yaitu lima profil situs web di Indonesia dievaluasi dan dinilai pada studi ini.
\end{abstract}

Kata Kunci: E-Commerce, EWAM, Metode, Statistik Deskriptif, TAM, TRA

\section{PENDAHULUAN}

\subsection{Latar Belakang}

Berdasarkan hasil survei Internet World Stats (30 Juni 2009) Asia memperoleh peringkat pertama jumlah pengguna Internet di dunia yaitu 704.213.930 pengguna disusul Eropa yang menduduki peringkat kedua dengan 402.380.474 pengguna. Jumlah pengguna Internet di Indonesia pada tahun 2009 mencapai 25 juta pengguna dari populasi penduduk Indonesia yang jumlahnya 240.271.522 jiwa. Pertumbuhan toko online dengan aplikasi e-commerce meningkat secara signifikan di Indonesia sehingga perlu dilakukan penelitian tingkat keberhasilan aplikasi e-commerce berdasarkan perspektif konsumen.

\subsection{Identifikasi Masalah}

Banyak situs-situs penjualan online yang berpenampilan menarik dan dilengkapi dengan aplikasi e-commerce namun tidak mampu menarik pengunjung untuk melakukan transaksi pembelian dan kembali lagi. Beberapa masalah yang menjadi perhatian peneliti adalah lemahnya kepercayaan konsumen dalam transaksi online, pemakaian kartu kredit di negara-negara berkembang masih relatif rendah, kelengkapan isi belum dimutakhirkan secara teratur, tidak terbuka dalam menentukan harga produk, biasanya harga produk akan diberitahu kepada konsumen ketika konsumen mengirim private message ke penjual, lambat dalam membalas e-mail yang dikirim oleh pelanggan, dan tidak menjaga data pribadi pelanggan. Untuk mengetahui kriteria-kriteria apa saja yang menentukan keberhasilan aplikasi e-commerce di Indonesia maka perlu diadakan penelitian.

\subsection{Studi sebelumnya}

Tabel 1.1 Metode EWAM yang digunakan pada riset sebelumnya

\begin{tabular}{|c|c|c|c|}
\hline No. & Sektor & Situs web & $\begin{array}{l}\text { Jumlah } \\
\text { asesor }\end{array}$ \\
\hline 1 & $\begin{array}{l}\text { Consumer } \\
\text { goods }\end{array}$ & $\begin{array}{l}\text { Swiss } \\
\text { webvan.com } \\
\text { (Best Practice) } \\
\text { le-shop.ch } \\
\text { migros.ch } \\
\text { mcfood.ch }\end{array}$ & 20 \\
\hline \multicolumn{4}{|c|}{ Referensi: Schubert \& Leimstoll (2001) } \\
\hline 2 & Grocery & $\begin{array}{l}\text { Swiss } \\
\text { shop.coop.ch } \\
\text { leshop.ch } \\
\text { migros-shop.ch } \\
\text { (Best Practice) } \\
\text { spar.ch } \\
\text { Australia } \\
\text { homeshop.com.au } \\
\text { groceries4u.com.au } \\
\text { greengrocer.com.au } \\
\text { aussieshopper.com.au } \\
\text { shopfast.com.au } \\
\text { colesonline.com.au } \\
\text { (Best Practice) }\end{array}$ & $\begin{array}{l}25 \\
\\
80 \\
\text { Jumlah } \\
\text { respons } \\
\text { dari } \\
\text { asesor 5- } \\
56 \text { orang }\end{array}$ \\
\hline \multicolumn{4}{|c|}{ Referensi: Leimstoll, Kurnia, \& Schubert (2005b) } \\
\hline 3 & $\begin{array}{l}\text { Selling } \\
\text { books } \\
\text { online }\end{array}$ & $\begin{array}{l}\text { Australia } \\
\text { Angus \& Robertson } \\
\text { Dymocks } \\
\text { Booktopia }\end{array}$ & $\begin{array}{l}14 \\
9 \\
31\end{array}$ \\
\hline
\end{tabular}




\begin{tabular}{|c|c|c|c|}
\hline & & $\begin{array}{l}\text { (Best Practice) } \\
\text { McGills } \\
\text { QBD The Book Shop } \\
\text { Reader's Refuge } \\
\text { Technical Book Shop } \\
\text { Swiss } \\
\text { Amazon } \\
\text { (Best Practice) } \\
\text { Bider \& Tanner } \\
\text { Books } \\
\text { Buch } \\
\text { Jaeggi }\end{array}$ & $\begin{array}{l}8 \\
17 \\
12 \\
12 \\
\\
\\
\\
\\
15 \\
14 \\
13 \\
16 \\
16\end{array}$ \\
\hline \multicolumn{4}{|c|}{ Referensi: Leimstoll, Kurnia, \& Schubert (2005a) } \\
\hline 4 & $\begin{array}{l}\text { Any } \\
\text { Sector }\end{array}$ & $\geq 3$ dan $\leq 7$ & 10 \\
\hline \multicolumn{4}{|c|}{ Referensi: Leimstoll (2009) } \\
\hline
\end{tabular}

Tabel 1.1 memperlihatkan hasil penelitian dengan metode EWAM pada sektor consumer goods, grocery dan books sebuah studi perbandingan di Negara Swiss dan Australia menemukan bahwa aplikasi-aplikasi e-commerce yang diteliti belum memenuhi ekspektasi dari konsumen

\subsection{Tujuan dan Kontribusi Penelitian}

Pertama, bagi Internet Vendor memberikan perbandingan dari kualitas yang berorientasi kepada konsumen dari situs web dengan profil sektornya atau kompetitor secara langsung dan rekomendasi perbaikan yang mungkin digambarkan pada hasilnya. Kedua, bagi Potential Internet Vendor meningkatkan kesadaran pentingnya mengetahui kriteria-kriteria sukses dari situs-situs web $e$ commerce. Ketiga, bagi Internet Buyers/Users menguji kualitas yang berorientasi kepada pelanggan dari situs web melalui pelanggan berbelanja secara online.

\section{MODEL, ANALISIS, DESAIN, DAN IMPLEMENTASI}

\subsection{Fase Transaksi pada Pasar Elektronik}

\section{Pasar Elektronik}

Malone, Yates dan Benjamin pada tahun 1987 (Selz dan Schubert, 1998) berargumentasi bahwa infrastruktur-infrastruktur TI yang baru akan memungkinkan untuk menghindari dan mengeliminasi perantara dalam sistem nilai dan rantai suplai secara khusus dan kemudian mengarah kepada munculnya pasar-pasar elektronik.

Pasar-pasar elektronika adalah pasar-pasar terpenting, institusi-institusi atau mekanismemekanisme yang menyediakan pelaku-pelaku pasar untuk mengalokasikan sumber-sumber daya.

\section{Fase Transaksi}

Sebuah transaksi bisa dibagi kedalam tiga fase yaitu Fase Informasi, Fase Kesepakatan, dan Fase Penyelesaian. Gambar 2.1 memperlihatkan urutan fase-fase transaksi tradisional.

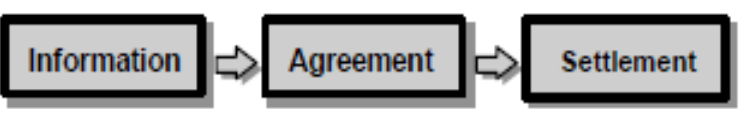

Gambar 2.1 Fase-fase Transaksi Tradisional

Sumber: Internet and the Digital Economy Track, 1998

\section{- Fase Informasi (Information Phase)}

Pada Fase Informasi pelanggan-pelanggan mengumpulkan informasi pada layanan-layanan dan produk-produk potensial. Mereka mencari kemungkinan pemasok-pemasok, menanyakan harga-harga dan persyaratan-persyaratannya. Fase Informasi mencakup kepuasan awal dari kebutuhankebutuhan konsumen atas informasi untuk konsiliasi permintaan-permintaan terhadap produk dan layanan beserta penawarannya.

\section{- Fase Kesepakatan (Agreement Phase)}

Negosiasi antara pemasok-pemasok dan pelanggan-pelanggan berlangsung dalam Fase Kesepakatan. Fase ini menyediakan penentuan kaitan ke sebuah perusahaan antara pemasok dan pembeli yang akan mengarah kepada sebuah kontrak, memperbaiki detail-detail misalnya spesifikasi produk, pembayaran, pengiriman dan lain-lain.

\section{- Fase Penyelesaian (Settlement Phase)}

Tahap konvensional terakhir disebut dengan Fase Penyelesaian. Pengiriman (fisik/virtual) dari produk yang dipesan akan berlangsung selama fase ini. Juga kemungkinan interaksi-interaksi setelah penjualan terjadi seperti jaminan jika terjadi klaim

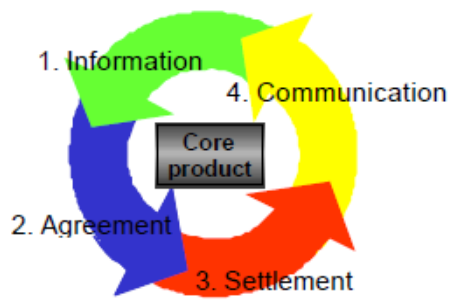

atau layanan help desk yang muncul.

Gambar 2.2 Model Fase Transaksi Berkelanjutan

Sumber: Internet and the Digital Economy Track, 1998

Di dalam lingkungan-lingkungan virtual, derajat interaksi yang lebih jauh menjadi isu sentral. Pembaca yang membeli buku dari Amazon.com secara otomatis adalah sumber potensial untuk resensi buku, karena seseorang sebenarnya juga 
akan membaca dulu buku yang akan dibeli. Jika banyak pembaca dengan selera yang sama dan cenderung untuk bergabung dengan keinginan dan usahanya sendiri, sebuah komunitas online dari orang-orang yang memiliki pikiran yang sama muncul menjadi sebuah eksistensi. Buah pikir dari komunitas berada di jantung dari revolusi Internet. Hasil pengembangan selanjutnya ditambahkan empat fase kepada proses transaksi-komunikasi seperti diperlihatkan pada Gambar 2.2.

\section{- Komponen}

\section{Komunitas} Component)

(Community

Konsep dari "Komunitas" menyediakan sebuah ikatan esensial antara dua transaksi. "Komunikasi" menempatkan diri antara pelanggan-pelanggan dan antara pelanggan dan perusahaan agar produk lebih erat kepadanya. Berbagi kepercayaan memungkinkan membangun komunitas yang membangkitkan level tertentu dari kepercayaan antara anggotanya masing-masing dan kemudian menginspirasikan sebuah lingkungan e-commerce yang subur. Spar dan Bussang pada tahun 1996 (Schubert \& Selz, 1998) menunjukkan bukti bahwa ketiadaan sebuah aturan-aturan bisnis yang dibentuk pada Internet bisa menghasilkan sebuah lingkungan komersial yang dipengaruhi oleh ketidakamanan.

\subsection{TAM dan TRA}

Technology Acceptance Model (TAM) Davis mendeskripsikan efek dari fitur-fitur sistem pada penerimaan pengguna kepada sistem informasi yang baru berbasiskan komputer. Davis memilih 'Fishbein Model', sebuah model tingkah laku secara psikologi sebagai dasar dari pengembangan TAM. Model ini dispesifikasikan oleh Fishbein pada tahun 1967, kemudian analisisnya dipertajam oleh Fishbein dan Ajzen tahun 1975 (Schubert, 2003) dan lebih jauh lagi dielaborasikan ke dalam Theory of Reasoned Action (TRA) yang terlihat pada Gambar 2.3.

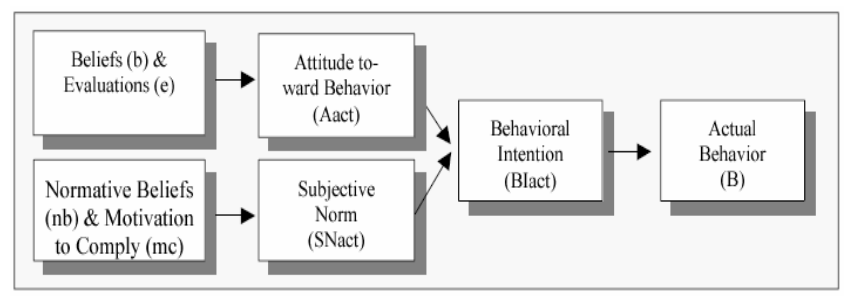

Gambar 2.3 Diagram Theory of Reasoned Action

(TRA)

Sumber: Schubert, 2003

TAM mengikuti rantai kausal dari TRA yaitu: "Attitude" $\rightarrow$ "Intention" $\rightarrow$ "Behaviour".

Berdasarkan rantai kausal tersebut David mengajukan model dasar TAM dalam bentuk diagram skematik yang dihasilkan dari studi empiris seperti terlihat pada
Gambar 2.4. Hubungan antara variabel-variabel individual adalah dalam bentuk panah-panah. Hubungan hipotetis didefinisikan dalam bentuk dasar yang diujikan secara empiris menggunakan kuesioner yang diikuti oleh analisis regresi.

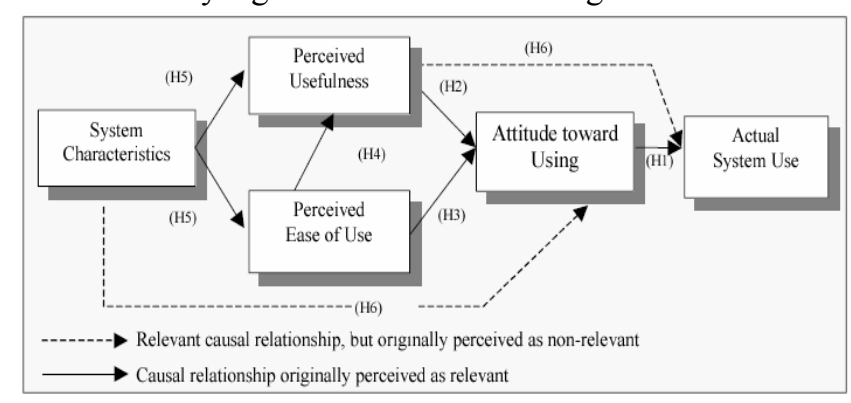

Gambar 2.4 Diagram Kausal Technology Acceptance Model (TAM)

Sumber: Schubert, 2003

TAM (Davis \& Venkatesh, 2000) berteori bahwa sebuah niat tingkah laku individu untuk menggunakan sebuah sistem ditentukan oleh dua kepercayaan: pertama, perceived usefulness, didefinisikan sebagai sejauh mana seseorang percaya bahwa dengan menggunakan sistem akan meningkatkan kinerja kerjanya, dan kedua, perceived ease of use, didefinisikan sebagai sejauh mana seseorang percaya bahwa dengan menggunakan sistem akan bebas dari usahanya.

Menurut Davis, dari 120 kuesioner yang dikirimkan kepada karyawan-karyawan di Laboratorium Pengembangan Toronto, Kanada, 112 kuesioner dikembalikan secara lengkap $(\mathrm{n}=185$, dimana 109 melalui e-mail dan 76 dengan XEDIT). Hasil evaluasi mengkonfirmasikan beberapa hipotesa sebagai berikut:

- (H1), "Attitude” memiliki pengaruh langsung kepada "Actual System Use".

- (H2), "Usefulness" memiliki efek yang signifikan kepada "Attitude toward Using".

- $(\mathrm{H} 3)+(\mathrm{H} 4)$, "Ease of Use" memiliki efek kepada "Attitude" dan "Usefulness".

Temuan-temuan lebih jauh yang tidak diharapkan dalam bentuk:

- (H5), "System” memiliki signifikan efek kepada "Ease of Use" tetapi tidak kepada "Usefulness".

- (H6), "Usefulness" memiliki sebuh efek langsung kepada "Actual System Use".

- (H7), "System" mempunyai sebuah efek langsung kepada "Attitude toward Using".

Variabel-variabel motivasi "Attitude toward Using", Perceived Usefulness", dan "Perceived Ease of Use" menyediakan sebuah kaitan antara fitur-fitur sistem dan tingkah laku dari individu 
dikaitkan dengan pemakaian sistem informasi yang baru (Actual System Use).

Di dalam TAM, "Subjective Norm" dari Model Fishbein tidak diintegrasikan, Davis tidak mempertimbangkannya. Fishbein dan Ajzein tahun 1975 (Davis \& Venkatesh, 2000) mendefinisikan Subjective Norm sebagai persepsi seseorang bahwa kebanyakan orang yang dianggap penting baginya berfikir bahwa dia seharusnya atau tidak seharusnya melakukan tingkah laku dengan bertanya sebelumnya.

Malhotra dan Galletta (1999) menyimpulkan dalam artikelnya berjudul "Extending the Technology Acceptance Model to Account for Social Influence, Theoritical Bases and Empirical Validation" bahwa Davis tidak memperhitungkan pentingnya "Subjective Norm" dalam TAM. Studi yang diujikan oleh mereka secara empiris menunjukkan kepada fakta bahwa pengaruhpengaruh sosial pengguna juga bermain dalam tugas penting yang dapat diterima dan penggunaan teknologi informasi yang baru. Pengaruh-pengaruh sosial diintegrasikan di dalam EWAM diwujudkan dalam bentuk kriteria yang dinamakan "Trust”.

\subsection{Extended Web Assessment Method (EWAM) Asumsi Dasar}

Metode EWAM dikembangkan pada tahun 2001 di Universitas Ilmu Terapan Basel, Swiss (Leimstoll, Kurnia \& Schubert, 2005) berdasarkan metode penilaian web terdahulu yang dikembangkan pada permulaan tahun 1997 oleh Petra Schubert dan Dorian Selz di Competence Centre for Electronic Markets (CCEM), Universitas St. Gallen, Swiss bekerjasama dengan perusahaan-perusahaan rekanan (Selz dan Schubert, 1998. 1999; Schubert dan Selz, 2001). EWAM mengintegrasikan temuan-temuan dari Technology Acceptance Model (TAM) dan Theory of Reasoned Action (TRA) dan beberapa pendekatan-pendekatan alternatif berikut (Schubert, 2003):

- Ekspektasi-ekspektasi dan peringkat-peringkat dari fitur-fitur kualitas situs Web: hasil dari dua studi pada persepsi pengguna;

- Desain kualitas dari situs-situs Web untuk ecommerce: evaluasi-evaluasi fortune 1000 webmaster;

- Dampak karakteristik-karakteristik situs Web yang diterima pada lalu lintas situs Web;

- Perfect Web pages;

- Web usage mining untuk evaluasi situs Web;

- GomezPro.com;

- JurisNET.

Schubert (2003) mengacu kepada analisis dan kategorisasi detail yang dilakukan oleh Totz et al. Berdasarkan artikel Totz et al., Schubert (2003) menyusun EWAM dalam kategori: (1) market focus (external visibility); (2) subjective (persepsi kualitas pelanggan); dan (3) attribute specific.

\section{Komponen-komponen EWAM}

Kombinasi EWAM dengan kategori-kategori Ease of Use, Usefulness, dan Trust diperlihatkan pada Gambar 2.5. Dimensi sektor "1..n" mengilustrasikan perluasan dari EWAM dengan profil-profil sektor dan mempertimbangkan perbedaan kriteria individual yang penting di dalam sektor-sektor ini.

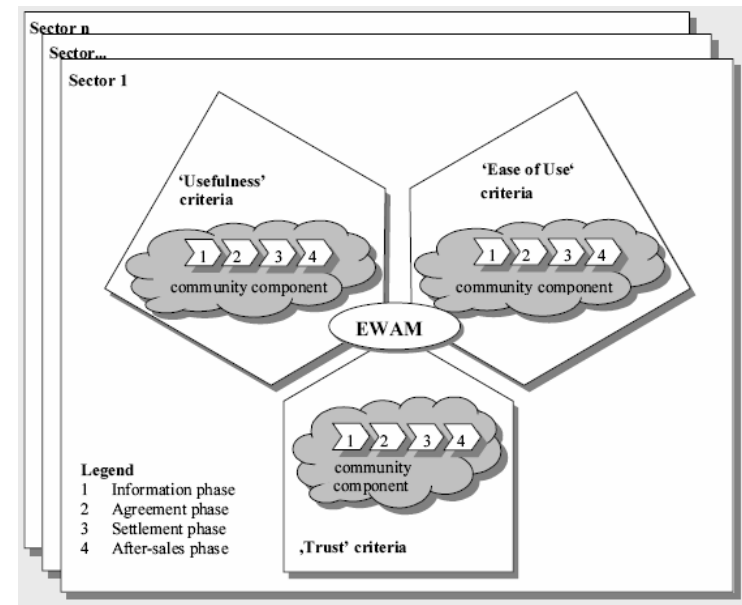

Gambar 2.5 Diagram Extended Web Assessment Method (EWAM)

Sumber: Schubert, 2003

\section{Peringkat Penting}

EWAM didasarkan kepada evaluasi ganda bagi setiap kriteria. Pertama, makna subyektif bagi sebuah atribut yang dideklarasikan oleh asesor. Kedua, evaluasi seluruh situs web di dalam sektor yang sama. Dalam kasus peringkat makna bernilai rendah ("--"), maka nilai evaluasi aktual (tahap kedua) hampir tidak diperlukan lagi.

\subsection{EWAM Tool}

EWAM tool merupakan kuesioner online yang dalam penelitian ini dibuat menggunakan Google Apps. Setiap asesor mengakses EWAM tool dengan mengetikkan URL: http://webatool.andipensil.com diikuti dengan melengkapi username dan password.

Ketika asesor mulai mengevaluasi, maka pertama kali asesor harus merekam Uniform Resource Locater (URL) dari situs web yang diuji dan menetapkan ke sektornya. Asesor harus memutuskan sebuah pernyataan positif atau negatif dengan nilainya masing-masing. Skala memiliki empat nilai $(++,+,-,--)$, alternatif nilai "n.a" (not applicable) bisa digunakan jika sebuah kriteria tidak relevan atau tidak tersedia dalam konteks tertentu. Evaluasi positif (negatif) akan mengarah kepada hasil positif (negatif). "Saya sangat setuju" (+2), "Saya setuju" (+1), "Saya tidak setuju" (-1), "Saya 
sangat tidak setuju" (-2). "N.a." bernilai nol (0) artinya diabaikan untuk kalkulasi lebih lanjut. Lima skala penilaian tersebut juga diterapkan pada penelitian evaluasi situs web e-commerce yang dilakukan oleh Merwe \& Bekker (2003).

\subsection{Laporan Penilaian Web Individu}

Berdasarkan kepada penilaian situs web, sebuah laporan penilaian web individu yang mengandung representasi grafis menghasilkan (Schubert dan Kurnia, 2004):

1. Ringkasan dari kriteria individu dan hasilhasilnya dalam fase-fase "Information Phase", "Agreement Phase", "Settlement Phase", "After-Sales Phase", "Community Component","Final Section", dan kalkulasi skor total.

2. Perbandingan situs-situs web (Company Profile) yang diuji dengan rata-rata sektor (Sector Profile) dan profil terbaik (Best Practice Profile) dalam analisis kuantitatif dan representasi grafis tanpa memperhatikan peringkat penting.

3. Perbandingan dalam bentuk grafik hasil-hasil dari enam kategori $(1,2)$ dengan peringkat penting.

4. Perbandingan seperti pada poin (2) diatas, namun dengan memperhatikan peringkat penting.

\subsection{Analisis dan Persiapan Data}

Dalam analisis data, EWAM tool mendefinisikan tiga profil yang menggambarkan evaluasi yang mengandung arti dari setiap web yang akan diuji:

- Sector Profile: profil dari sektor yang relevan. Penjualan buku online adalah sektor yang dipilih pada riset ini.

- Company Profile: Profil dari situs web. Terdapat empat profil situs web yang diuji yaitu balaipustakaonline.com, gramediaonline.com, erlangga.co.id, dan kutukutubuku.com. Situs web amazon.com dijadikan Standar De Facto pada riset ini.

- Best Practice Profile: profil yang berkembang paling baik dalam sektor yang relevan. Profil yang dipilih adalah sesuai dengan hasil evaluasi.

\subsection{Strategi Umum EWAM}

Gambar 2.6 memperlihatkan perbandingan hasilhasil dari kategori-kategori individu dengan peringkat makna bagi profil perusahaan dan sektor. Diperlihatkan dua matriks, kemudian dibagi lagi menjadi empat seksi dimana hasil dari setiap kategori seharusnya secara ideal berada pada garis atau di atas garis diagonal. Tabel 2.1 berikutnya berisi deskripsi rekomendasi-rekomendasi yang seharusnya diterapkan tergantung dari hasil bermacam-macam seksi.

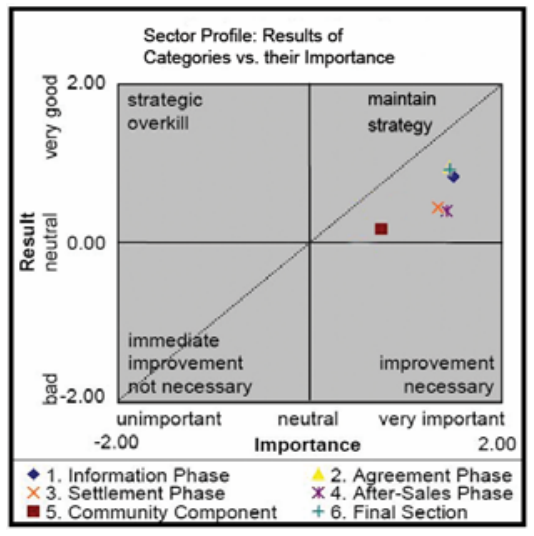

Gambar 2.6 Perbandingan hasil dari peringkat pentingnya kriteria

Sumber: Schubert \& Dettling, 2002

Tabel 2.1 Evaluasi Strategi

\begin{tabular}{|l|l|}
\hline \multicolumn{1}{|c|}{ Strategi } & \multicolumn{1}{|c|}{ Hasil } \\
\hline $\begin{array}{l}\text { Strategic } \\
\text { Overkill }\end{array}$ & $\begin{array}{l}\text { Entri-entri pada bidang kiri } \\
\text { atas mengindikasikan hasil yang } \\
\text { (sangat) baik dalam kategori- } \\
\text { kategori yang (kurang) tidak } \\
\text { penting. Ketersediaan sumber- } \\
\text { sumber daya kemungkinan tidak } \\
\text { dapat diterapkan secara efektif }\end{array}$ \\
\hline $\begin{array}{l}\text { Maintain } \\
\text { Strategy }\end{array}$ & $\begin{array}{l}\text { Entri-entri pada bidang } \\
\text { kanan atas mengindikasikan } \\
\text { hasil yang (sangat) baik dalam } \\
\text { kategori-kategori yang (sangat) } \\
\text { penting }\end{array}$ \\
\hline $\begin{array}{l}\text { No } \\
\text { immediate } \\
\text { improvement } \\
\text { necessary }\end{array}$ & $\begin{array}{l}\text { Entri-entri pada bidang kiri } \\
\text { yang mengindikasikan hasil } \\
\text { kategori-kategori yang (kurang) } \\
\text { tidak penting burat }\end{array}$ \\
\hline $\begin{array}{l}\text { Improvement } \\
\text { necessary }\end{array}$ & $\begin{array}{l}\text { Entri-entri pada bidang } \\
\text { kanan bawah mengindikasikan } \\
\text { hasil yang (sangat) buruk dalam } \\
\text { kategori-kategori yang (sangat) } \\
\text { penting }\end{array}$ \\
\hline
\end{tabular}

Sumber: Schubert, 2003

\subsection{Penurunan Matematika}

Paragraf berikut ini mendeskripsikan kalkulasi bagi perbandingan dari situs-situs web yang diuji dengan rata-rata dan dengan Best Practice Profile dari sektor, termasuk tingkat pentingnya kriteria, 
bagi Sector Profile. Kalkulasi bagi Company Profile dan Best Practice Profile adalah sama (Schubert, 2003).

Tabel 2.2 Kriteria $\mathrm{X}_{\mathrm{i}}$, Importance $\mathrm{W}_{\mathrm{i}}$ \& $\mathrm{Wg}_{\mathrm{i}}$, Evaluasi $\mathrm{r}_{\mathrm{i}}$, Weighted Value $\mathrm{R}_{\mathrm{i}}$

\begin{tabular}{|l|l|l|l|l|}
\hline $\begin{array}{l}\text { Kriteria: } \\
X_{i}\end{array}$ & $\begin{array}{l}\text { Importance: } \\
\begin{array}{l}\text { W } \\
\text { (range -2 } /+2)\end{array}\end{array}$ & $\begin{array}{l}\text { Importance: } \\
\text { Wg } \\
\text { (range 0-1) }\end{array}$ & $\begin{array}{l}\text { Evaluasi: } \\
r_{i} \\
\text { (range -2 } \\
+2)\end{array}$ & $\begin{array}{l}\text { Weighted } \\
\text { Value: } \\
R=W g * \overline{r_{i}}\end{array}$ \\
\hline $\mathrm{X} 1$ & $\mathrm{~W}_{1}$ & $\mathrm{Wg}_{1}$ & $\overline{r_{1}}$ & $\mathrm{R}_{1}$ \\
\hline $\mathrm{X} 2$ & $\mathrm{~W}_{2}$ & $\mathrm{Wg}_{2}$ & $\overline{r_{2}}$ & $\mathrm{R}_{2}$ \\
\hline$\ldots$ & $\ldots$ & $\ldots$ & $\ldots$ & $\ldots$ \\
\hline $\mathrm{X} 26$ & $\mathrm{~W}_{26}$ & $\mathrm{Wg} x$ & $\overline{r_{26}}$ & $\mathrm{R}_{26}$ \\
\hline
\end{tabular}

Tabel 2.3 Kategori $\mathrm{K}_{1}-\mathrm{K}_{6}$

\begin{tabular}{|c|l|}
\hline Kategori $K_{k}$ & Deskripsi \\
\hline $\mathrm{K}_{1}$ & 1. Information Phase \\
\hline $\mathrm{K}_{2}$ & 2. Agreement Phase \\
\hline $\mathrm{K}_{3}$ & 3. Settlement Phase \\
\hline $\mathrm{K}_{4}$ & 4. After-Sales Phase \\
\hline $\mathrm{K}_{5}$ & 5. Community Component \\
\hline $\mathrm{K}_{6}$ & 6. Final Section \\
\hline
\end{tabular}

1. Transformasi dari peringkat penting sebuah kriteria

Evaluasi kriteria individual dan peringkat penting menggunakan skala dari (-2) sampai $(+2)$. Untuk menghindari masalah terjadinya perkalian dua bilangan negatif, maka peringkat penting dari kriteria individu $\left(\mathrm{W}_{\mathrm{i}}\right)$ ditransformasikan kedalam jangkauan dari (0) sampai (1) $\left(\mathrm{Wg}_{\mathrm{i}}\right)$.

$$
\mathrm{Wg}_{\mathrm{i}}=\frac{1}{4}\left(W_{i}+2\right)
$$

2. Evaluasi rata-rata untuk setiap kriteria

$$
\bar{r}_{i}=\frac{1}{m} \sum_{j=1}^{m} r_{i j}
$$

dimana

$\mathrm{m}=$ jumlah asesor yang mengevaluasi sebuah kriteria Xi

$\mathrm{R}_{\mathrm{ij}}=$ hasil individu dari sebuah kriteria di dalam jangkauan $(-2 /+2)$

3. Perkalian hasil rata-rata dengan peringkat penting
Hasil definitif bagi setiap kriteria muncul dengan mengalikan hasil rata-rata dari setiap kriteria $\left(\bar{r}_{i}\right)$ dengan peringkat pentingnya $\left(\mathrm{Wg}_{\mathrm{i}}\right)$. Sehingga kriteria hanya akan mencapai nilai tertinggi ketika peringkat pentingnya $\left(\mathrm{W}_{\mathrm{i}}=1\right)$ adalah tinggi. Dengan nilai peringkat penting yang lebih rendah $\left(1 \geq \mathrm{W}_{\mathrm{i}} \geq\right.$ $0)$ hasil akhir dari kriteria akan menurun, namun tidak akan jatuh di bawah nol.

$$
\mathrm{Ri}=\overline{r_{i}} * \mathrm{Wg}_{\mathrm{i}}
$$

4. Penjumlahan evaluasi individual per kategori

Hasil untuk kategori $\left(K_{k}, k=1 . .6\right)$ tiba dengan menambahkan $\mathrm{R}_{\mathrm{i}}$ per kategori. Contoh pada Information Phase $\left(\mathrm{K}_{1}\right)$ dan Agreement Phase $\left(\mathrm{K}_{2}\right)$ diberikan di bawah ini:

$$
\begin{aligned}
& \mathrm{K}_{1}=\sum_{i=1}^{8} R_{i} \\
& \mathrm{~K}_{2}=\sum_{i=9}^{10} R_{i}
\end{aligned}
$$

5. Kalkulasi persentase pencapaian skor teratas dari $\mathrm{K}_{\mathrm{i}}$

a) Kalkulasi dari evaluasi minimum $\left(\mathrm{R}_{\mathrm{MINi}}\right)$ dan maksimum $\left(\mathrm{R}_{\mathrm{MAXi}}\right)$ untuk sebuah kriteria dengan peringkat penting di dalam jangkauan (0-1).

$$
\begin{array}{ll}
\mathrm{R}_{\mathrm{MINi}}=\mathrm{Wg}_{\mathrm{i}} *-2 & -2 \leq \mathrm{R}_{\mathrm{MINi}} \leq 0 \\
\mathrm{R}_{\mathrm{MAXi}}=\mathrm{Wg}_{\mathrm{i}} * 2 & 0 \leq \mathrm{R}_{\mathrm{MAXi}} \leq 2
\end{array}
$$

b) Kalkulasi dari evaluasi minimum $\left(\mathrm{R}_{\mathrm{MINi}}\right)$ dan maksimum $\left(\mathrm{R}_{\mathrm{MAXi}}\right)$ untuk sebuah kategori. Contoh yang diberikan untuk Information Phase $\left(\mathrm{K}_{\mathrm{k}, \mathrm{k}=1}\right)$.

$$
\mathrm{K}_{\mathrm{MIN} 1}=\sum_{i=1}^{8} R_{M I N i}
$$

$$
\mathrm{K}_{\mathrm{MAX} 1}=\sum_{i=1}^{8} R_{M A X i}
$$

c) Kalkulasi persentase pencapaian skor tertinggi

$$
\mathrm{K} \% \%_{\mathrm{k}}=\frac{\left(K_{k}+K_{M A X i}\right)}{\left(K_{M A X i}+\left(K_{M I N i} *-1\right)\right.} * 100 \%
$$

disederhanakan menjadi 


$$
\mathrm{K} \%{ }_{\mathrm{k}}=0.5\left(\frac{K_{k}}{K_{M A X i}}+1\right) * 100 \%
$$

6. Transformasi $\mathrm{K} \%{ }_{\mathrm{k}}$ di dalam jangkauan $(-2 /+2)$

Dalam analogi-analogi yang lebih jauh hasil sebuah kategori $\left(K_{k}\right)$ seharusnya dibandingkan dengan peringkat pentingnya. Sebagai tambahan hasil $\mathrm{K} \% \mathrm{k}_{\mathrm{k}}$ ditransformasikan ke dalam jangkauan $(-2 /+2)$ sebagai hasil definitif dari kategori ini $\left(\mathrm{KR}_{\mathrm{k}}\right)$.

$$
\mathrm{KR}_{\mathrm{k}}=\left(\frac{K \%_{k}}{100} * 4\right)-2
$$

7. Perbandingan dari hasil kategori-kategori individual $(K R)$ dengan peringkat pentingnya.

Kalkulasi nilai rata-rata level penting dari kriteria individu $\left(\mathrm{W}_{\mathrm{i}}\right)$ untuk kategori tertentu $\left(\mathrm{K}_{\mathrm{k}}\right)$. Pada Fase Informasi sebagai contoh:

$$
\mathrm{KW}_{\mathrm{k}}=\frac{1}{8} \sum_{i=1}^{8} W_{i}
$$

\section{Skor Keseluruhan}

Skor keseluruhan adalah hasil final dari sebuah profil (PR). Skor ini dihitung dari jumlah enam kategori (KS) dalam keterhubungannya kepada hasil maksimum teoritis profilnya masing-masing.

a) Kalkulasi jumlah seluruh kategori (KS)

$$
\mathrm{Ks}_{\mathrm{o}}=\sum_{k=1}^{6} K_{k}
$$

dimana o $(o=1 . .3)$ merupakan indeks dari ketiga profil. (Sector Profile: o = 1)

b) Kalkulasi persentase pencapaian skor tertinggi KS

Kalkulasi yang sama dengan 5c), namun seluruh kategori $(\mathrm{k}=1 . .6)$. Persentase pencapaian skor tertinggi dari $\mathrm{KS} \%{ }_{0}$ dihitung dengan rumus berikut:

$$
\mathrm{KS} \%_{\mathrm{o}}=\frac{\left(K S_{o}+R S_{\text {MAXo }}\right)}{\left.R S_{\text {MAXo }}+R S_{\text {MINo }}-1\right)} * 100 \%
$$

Dimana

$\mathrm{RS}_{\mathrm{MAX}}=$ Skor maksimal teoritis dari seluruh kriteria dalam profil o

$\mathrm{RS}_{\mathrm{MINo}}=$ Skor minimal teoritis dari seluruh kriteria dalam profil o

disederhanakan menjadi:

$$
\mathrm{KS} \%_{\mathrm{o}}=0.5\left(\frac{K S_{o}}{R S_{\text {MAXo }}}+1\right) * 100 \%
$$

c) Transformasi dari $\mathrm{KS} \%{ }_{0}$ di dalam jangkauan $(-2 /+2)$

$$
\mathrm{PR}_{\mathrm{o}}=\left(\frac{K S \%_{o}}{100} * 4\right)-2
$$

Sebagai contoh Sector Profile dengan nilai 1.02, berarti "baik" pada skala $(-2 /+2)$. Interpretasi yang relevan adalah: "Dalam sektor ini tampilan web dianggap baik di dalam rata-rata sektor".

\section{METODOLOGI}

\subsection{Desain Riset}

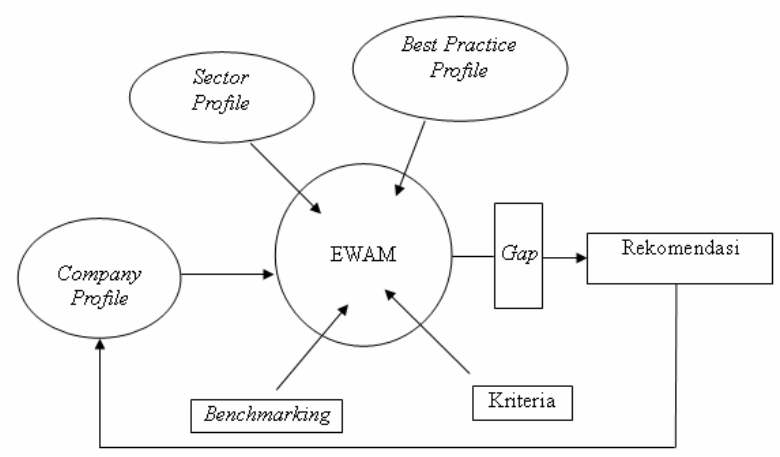

Gambar 3.1 Desain riset evaluasi aplikasi e-commerce

Gambar 3.1 mengilustrasikan kerangka konseptual penelitian ini. Setiap Company Profile (situs web) dievaluasi dan hasil penilaiannya dibandingkan dengan Best Practice Profile (situs web dengan skor tertinggi) dan Sector Profile (nilai rata-rata dari seluruh situs web yang diuji), Gap akan ditemukan dari hasil perbandingan profil terhadap profil terbaik dan ekspektasi konsumen, maka rekomendasi diperlukan untuk memperbaiki situs web dengan kinerja yang dinilai kurang baik. 


\subsection{Metode Riset}

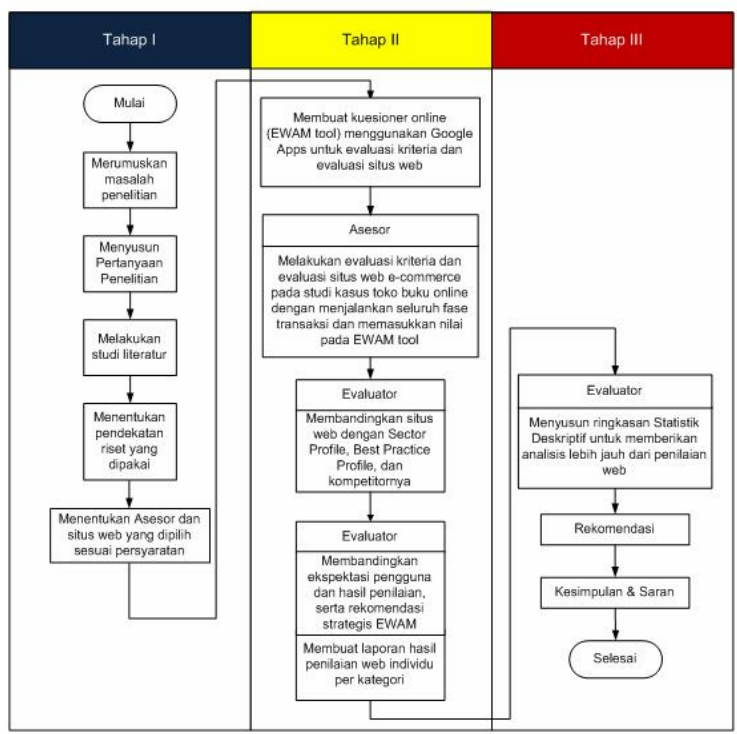

Gambar 3.2 Tahap-tahap pelaksanaan penelitian yang dilakukan

Penelitian ini dilaksanakan melalui tiga tahap seperti terlihat pada Gambar 3.2 yaitu

- Tahap I: Merumuskan masalah yang akan diteliti, melakukan studi literatur terkait dengan aspek-aspek yang akan diteliti, dan menentukan jumlah asesor yang akan menilai.

- Tahap II: Membuat instrumen kuesioner secara online terdiri dari formulir evaluasi kriteria dan formulir evaluasi situs web dari EWAM tool yang dibuat menggunakan Google Apps. Setiap asesor akan melakukan dua penilaian yaitu evaluasi situs web dan evaluasi kriteria. Setelah seluruh asesor melakukan penilaian maka peneliti mengambil data tersebut dari Google Docs.

- Tahap III: Melakukan analisis data secara lengkap dan membuat kesimpulan.

\section{TEMUAN EWAM: SEKTOR BUKU}

Penentuan situs web dipilih pada riset ini berdasarkan persyaratan berikut:

- Toko buku online sebagai situs web profil menggunakan aplikasi e-commerce yang memnuhi fase transaksi dalam pasar elektronik.

- Toko buku online tersebut memiliki nama domain sendiri dan berada di wilayah Indonesia.

- Bukan organisasi non profit dan bukan berupa blog, situs web profil hanya menjual buku saja baik tercetak atau $e$-book untuk menghindari adanya bias antar sektor.

Jumlah situs web yang diuji adalah empat toko buku online yang berada di Indonesia sebagai situs web profil (Company Profile) sedangkan amazon.com dalam penelitian ini dijadikan sebagai Standar De Facto.

Dalam penentuan asesor terdapat sejumlah persyaratan yang harus dipenuhi oleh asesor untuk dapat melaksanakan penilaian web menggunakan EWAM tool (Leimstoll, Kurnia, \& Schubert, 2005a):

- Mereka harus memahami secara penuh kriteria dari formulir penilaian web dan mereka harus diinstruksikan secara menyeluruh.

- Mereka harus merupakan pengguna-pengguna web yang berpengalaman.

- Mereka harus menyediakan waktu untuk melewati empat fase transaksi secara utuh dari setiap situs web yang dinilai (termasuk pengiriman dan pembayaran).

Berdasarkan kriteria pemilihan asesor di atas (Leimstoll, Kurnia, \& Schubert, 2005a) maka peneliti mengambil sebanyak 20 orang asesor yang terdiri dari 17 asesor dari mahasiswa tingkat akhir di Magister Teknologi Informasi (MTI-UI), Fakultas Ilmu Komputer, Universitas Indonesia; 2 orang terdiri dari staf pengajar dan praktisi di bidang Ilmu Komputer dari institusi yang berbeda; dan 1 orang lagi mahasiswa tingkat akhir program pascasarjana Universitas Gunadarma. Seluruh asesor pernah melakukan transaksi online dan mereka sudah memiliki cukup pengalaman dalam dunia Internet ditunjukkan dari pengalaman lebih dari 4 tahun. Instruksi kepada asesor secara menyeluruh berkaitan dengan proses evaluasi kriteria dan evaluasi situs web dilakukan melalui EWAM tool.

Bagaimanapun juga, EWAM tool adalah sebuah proses yang membutuhkan pengetahuan yang tinggi, sehingga peneliti tidak bisa mengambil sampel secara acak dari konsumen yang akan melakukan penilaian.

Tabel 4.1 merangkum jumlah asesor yang menilai situs-situs web toko buku online di Indonesia.

Tabel 4.1 Situs-situs web dan jumlah asesor

\begin{tabular}{|l|c|}
\hline \multicolumn{1}{|c|}{ Situs web } & $\begin{array}{c}\text { Jumlah } \\
\text { Asesor }\end{array}$ \\
\hline www.amazon.com & 19 \\
\hline www.balaipustakaonline.com & 20 \\
\hline www.erlangga.co.id & 19 \\
\hline www.gramediaonline.com & 19 \\
\hline www.kutukutubuku.com & 20 \\
\hline
\end{tabular}

Tabel 4.2 Peringkat penting dari setiap kategori

\begin{tabular}{|l|c|}
\hline \multicolumn{1}{|c|}{ Fase } & $\begin{array}{c}\text { Peringkat Penting } \\
\text { (Jangkauan }-2 /+2)\end{array}$ \\
\hline Information Phase & 1.47 \\
Agreement Phase & 1.45 \\
Settlement Phase & 1.35 \\
\hline
\end{tabular}




\begin{tabular}{|l|l|} 
After-Sales Phase & 1.42 \\
Community Component & 0.74 \\
Final Section & 1.47 \\
\hline
\end{tabular}

Tabel 4.2 memperlihatkan ringkasan hasil evaluasi kriteria yang dievaluasi oleh 19 asesor. Seluruh asesor menyatakan penting kriteria pada 5 fase yaitu Information Phase (1.47) dan Final Section (1.47), Agreement Phase (1.45), After-Sales Phase (1.42), Settlement Phase (1.35), sedangkan Community Component (0.74) dianggap tidak terlalu penting oleh asesor.

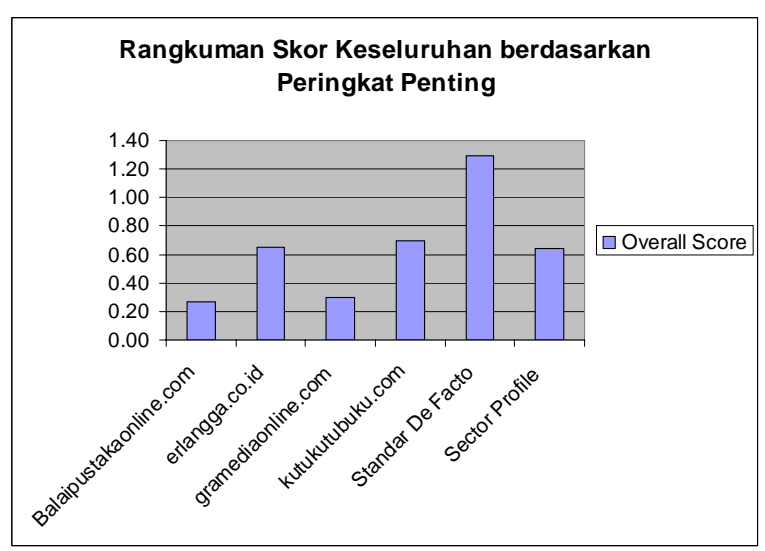

Gambar 4.1 Rangkuman penilaian situs web dengan peringkat penting

Ringkasan skor penilaian situs web berdasarkan peringkat penting menemukan kutukutubuku.com memperoleh skor tertinggi (0.73) sehingga menjadi Best Practice Profile disusul oleh erlangga.co.id (0.67), gramediaonline.com (0.35), dan terakhir balaipustakaonline.com (0.31) mendapatkan peringkat terendah.

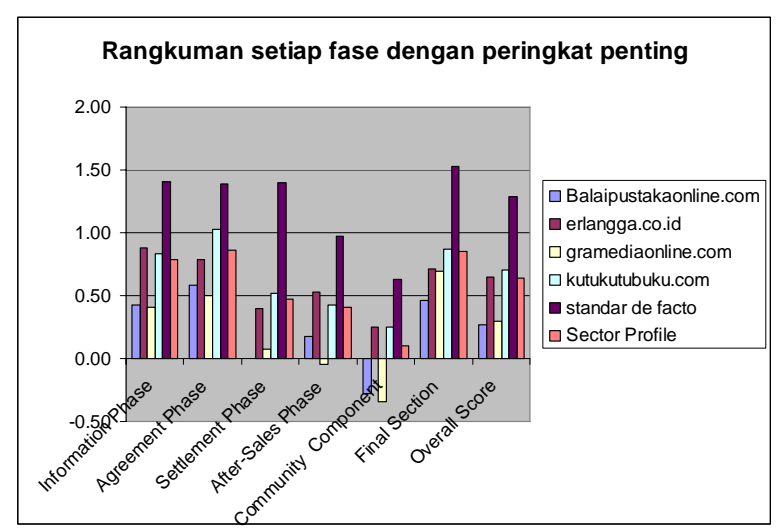

Gambar 4.2 Rangkuman penilaian toko buku online per fase dengan Peringkat Penting

Gambar 4.1 memperlihatkan rangkuman penilaian situs web berdasarkan peringkat penting. kutukutubuku.com memperoleh skor tertinggi, sedangkan balaipustakaonline.com menjadi situs web dengan performa terburuk.

Gambar 4.2 memperlihatkan lebih jauh rangkuman hasil evaluasi situs web per fase dengan peringkat penting. Amazon.com sebagai situs web aplikasi e-commerce Standar De Facto memperoleh skor tertinggi pada setiap fase, kutukutubuku.com memperoleh peringkat tertinggi dari situs web lokal yang diuji (Best Practice Profile) disusul erlangga.co.id, balaipustakaonline.com, dan gramediaonline.com mendapatkan nilai terendah berada di bawah rata-rata sektor.

\section{KESIMPULAN}

Peneliti menyadari bahwa studi empiris dengan sekumpulan sampel 20 orang asesor hanya dapat merefleksikan gambaran terbatas di dalam sebuah sektor. Penilaian aplikasi e-commerce secara keseluruhan oleh 20 orang dari Indonesia tidaklah bisa mewakili ribuan pengguna web di Indonesia dalam transaksi B2C. Meskipun demikian EWAM adalah proses yang membutuhkan pengetahuan yang tinggi sehingga peneliti tidak bisa meminta sampel secara acak dari orang yang akan melakukan evaluasi. Oleh karena itu situs web yang diuji juga dipilih per sektor untuk menghindari bias yang mungkin terjadi dan diseleksi sebagai pelaku-pelaku bisnis yang serius dalam menjalankan bisnis toko buku online.

Keberhasilan riset ini sangat ditentukan oleh pemahaman instruksi yang dipelajari oleh asesor pada EWAM tool, keterlibatan asesor secara menyeluruh dan mendalam dalam melakukan penilaian situs web dan evaluasi kriteria pada seluruh fase dalam EWAM, pengalaman asesor sebelumnya dalam transaksi elektronik, dan ketelitian dalam melakukan analisis kualitatif dan kuantitatif deskriptif dengan memperhatikan berbagai aspek dari profil sektor yang dievaluasi dan hukum transaksi elektronik yang berlaku pada saat riset dilakukan.

Penelitian lanjutan bisa dilakukan dengan mengambil beberapa situs web e-commerce dalam sektor yang sama yang dipilih secara selektif minimal tiga situs sampai maksimal tujuh situs web (Leimstoll, 2009), semakin banyak hasil evaluasi akan menghasilkan semakin banyak informasi sehingga memberikan petunjuk kriteria-kriteria pada fase-fase tertentu dapat memberikan kontribusi yang lebih besar kepada ekspektasi konsumen.

\section{Daftar Pustaka}

Kurnia dan Schubert (2004). An Evaluation of Online Grocery Services in Australia from a Consumers' Viewpoint. Proceedings of the Twelfth CollECTeR Workshop on eCommerce, 7./8. May, 2004, Adelaide, Australia. Diakses 
pada 10 Oktober 2009 dari http://bas.unikoblenz.de/bas/publications.nsf/c5afffd09db54d $89 \mathrm{c} 12572180036 \mathrm{e} 1 \mathrm{~b} 1 / 29 \mathrm{e} 57225 \mathrm{ac} 2257 \mathrm{f} 0 \mathrm{c} 1257$ 359004908a7/\$FILE/Collecter2004 final.pdf.

Kurnia, Schubert, Leimstoll (2005b). An Evaluation of Australian and Swiss E-Shops in the Grocery Sector, Proceedings of the 38th HICSS Conference, Hawaii, 2005. URL: http://bas.unikoblenz.de/bas/publications.nsf/c5afffd09db54d 89c12572180036e1b1/c71d7da9f4af8454c1257 359004908c0/\$FILE/HICSS_kurnia_et_al_cop yright.pdf. Diakses tanggal 10 Oktober 2009

Leimstoll, Kurnia, dan Schubert (2005a). Selling Books Online: An Evaluation of Australian and Swiss E-Shops, Proceedings of the 18th Bled eConference, eIntegration in Action, Bled, Slovenia, June 6-8 2005.

Diakses pada 10 Oktober 2009 dari http://bas.uni-

koblenz.de/bas/publications.nsf/c5afffd09db54d 89c12572180036e1b1/833f1801ba656351c1257 359004908ce/\$FILE/40_Leimstoll_Kurnia_Schu bert.pdf.

Malhotra \& Galletta (1999). Extending the Technology Acceptance Model to Account for Social Influence: Theoretical Bases and Empirical Validation. Proceedings of the 32nd Hawaii International Conference on System Sciences, 1999. URL:

http://www.brint.org/technologyacceptance.pdf. Diakses tanggal 12 November 2009

Merwe dan Bekker (2003). A Framework and methodology for evaluating e-commerce Web sites. Internet Research; 2003; 13, 5; ABI/INFORM Global. pg. 330.

Diakses pada 10 November 2009 dari http://proquest.umi.com/pqdweb.

Schubert \& Leimstoll (2001). The Extended Web Assessment Method (EWAM) applied: do websites for consumer goods stand the test?. Schoop, Mareike; Walczuch, Rita (Hrsg.), Eighth Research Symposium on Emerging Electronic Markets RSEEM 01, 16 - 18 September 2001, Maastricht, The Netherlands, Workshop Papers, S. 53-59, Maastricht: International Institute of Infonomics, 2001. URL: http://bas.unikoblenz.de/bas/publications.nsf/c5afffd09db54d 89c12572180036e1b1/ecda919da2ef6f08c12573 59004908c9/\$FILE/The\%20Extended\%20Web $\% 20$ Assessment $\% 20$ Method\%20Applied.pdf. Diakses tanggal 10 Oktober 2009

Schubert (2003). Extended Web Assessment Method (EWAM)-Evaluation of Electronic Commerce Applications from the Customer's Viewpoint, in: International Journal of Electronic Commerce, Vol. 7, No. 2, Winter 2002-2003. Diakses pada 12 November 2009 dari koblenz.de/bas/publications.nsf/a3f18119c0cb8f e3c12572180036eb5c/5f4066937bf8a021c12573 59004908cc/\$FILE/schubert_ijec_2003.pdf.

World Internet Users and Population Stats. Diakses pada 14 September 2009 dari http://www.internetworldstats.com/stats.htm.

\section{Penulis}

$02.2008-01.2010$

Master Degree in Information Technology, Faculty of Computer Science, Universitas Indonesia, Jakarta

09.1993 -- 03.1998

Bachelor Degree in Computer Engineering Department, Faculty of Computer Science, Universitas Gunadarma, Depok

\section{Publikasi}

Andi Susilo, Riri Satria, Widijanto Satyo Nugroho, Evaluasi Aplikasi E-Commerce pada Sektor Penjualan Buku Online dari Perspektif Konsumen di Indonesia menggunakan Extended Web Assessment Method (EWAM). Prosiding Seminar Nasional Aplikasi Teknologi Informasi 2010 (SNATI 2010), June $19^{\text {th }} 2010$, pp. B-84, Universitas Islam Indonesia (UII) (ISSN 1907-5022)

Andi Susilo, Syamsul Abbas Ras, Prototipe Rancangan Penentuan Jumlah Kendaraan pada Zona Penyangga TPA Sampah. Prosiding Seminar Nasional Teknologi (SNT) 2007: Teknologi untuk Kesejahteraan dan Peradaban Bangsa, pp. C-9-C-19. Collaboration between Kopwil V DIY, STMIK AMIKOM Yogyakarta, STMIK AKAKOM Yogyakarta, Universitas Islam Indonesia, Universitas Kristen Duta Wacana, and Universitas Atma Jaya, Jogjakarta (ISSN 1978-9777)

Andi Susilo, Mechanical and Electronics Design Methodology for Technical Product Optimazation. Prosiding Seminar Nasional Teknoin 2005, "Intelligent Control for Manufacturing System", pp. 7-13, Jurnal Teknologi Industri, Fakultas Teknologi Industri, Universitas Islam Indonesia, Jogjakarta (ISSN 0583- 8697)

Andi Susilo, Bagaimana menggunakan Program AVSIM51 Versi 1.30 untuk Simulasi Mikrokontroller 8031 (How to use AVSIM51 Versi 1.30 program for simulating Microcontroller 8031), Majalah Ilmiah Informatika, Vol. 4, No. 13, pp. 17-77, December 2002 (ISSN 1411-6413)

Andi Susilo, Proses Kreatif: Edison dan Bell dalam Revolusi Komunikasi (Creative Process: Edison and Bell in Revolution of Communication), Majalah Ilmiah Informatika, Vol. 4, No. 10, pp. 36-58, March 2002 (ISSN 1411-6413) 
Andi Susilo, Membangun Konverter Analog ke Digital Successive Approximation ADC0809 (Building Analog to Digital Converter Successive Approximation ADC0809), Majalah Ilmiah Informatika, Vol. 3, No. 8, pp. 9-18, September 2001 (ISSN 1411-6413)

Andi Susilo, Pembuatan Interface Card PPI8255: Kontrol Alat melalui Komputer (Building Interface card PPI8255: Controlling Device via Computer), Majalah Ilmiah Informatika, Vol. 2, No. 6, pp. 1-26, March 2001 (ISSN 1411-6413)
Andi Susilo, Analisa dan Rancangan Sederhana untuk Antarmuka Komputer dengan Transistor dan Op-Amp (Analyzing and Designing for Interfacing of Computer with Transistor and Op-Amp), Majalah Ilmiah Informatika, Vol. 2, No. 4, pp. 108-136, September 2000 (ISSN 1411-6413)

Andi Susilo, Akses Internet melalui Teknologi WAP (Accessing Internet through WAP Technology), Majalah Ilmiah Informatika, Vol. 2 No. 4, November 2000 (ISSN 1411-6413) 